\title{
Solution of high velocity anomalies imperceptible to seismic resolution, by means of synthetic models, Penobscot Field, Canada
}

The Mining-Geology-Petroleum Engineering Bulletin UDC: 550.8

DOI: 10.17794/rgn.2019.1.7

Review scientific paper

\author{
Wilmer Emilio García Moreno ${ }^{1,2}$; Iván Daniel Omaña Galeano․ \\ ${ }^{1}$ Sartenejas, Baruta, Miranda State, Metropolitan District (Simón Bolivar University) 89000 \\ ${ }^{2}$ Altamira, Chacao, Miranda State, Metropolitan District Venezuela \\ (Latin American Data Processing Center-BGP International of Venezuela) 01060
}

\begin{abstract}
Penobscot Field is located in the Sable Sub-basin in Nova Scotia, Canada, where a $3 \mathrm{D}$ seismic acquisition campaign was carried out in 1991 and also two oil wells were previously drilled (L-30 and B-41). In the interpreted seismic data, a discrepancy was found in the travel times of the seismic waves near well B-41, causing a false structural height in the Naskapi Member, Mississauga Formation (Early Cretaceous or Lower Cretaceous) and deeper formations (10 to 15 ms, i.e. approximately $25 \mathrm{~m}$ ). It was decided to find a solution of this problem using synthetic models. First, making a delimitation of the study area by means of a seismic subcube, which were later interpreted surfaces of interest, through the well data. The average velocity and density properties were found for each interpreted strata. Subsequently, a $2 \mathrm{D}$ seismic acquisition was simulated, choosing a line that crossed both wells and through the use of ray traces, synthetic shot gathers were obtained and processed through the use of different seismic migration tests, and the final solution was found to be Kirchhoff pre-stacking migration in depth.
\end{abstract}

\section{Keywords:}

High Velocity Anomaly; Mississauga Formation; Nova Scotia, Canada; Lower and Upper Cretaceous; Ray Tracing; Kirchhoff PSTM and PSDM.

\section{Introduction}

In the hydrocarbon exploration stage, seismic methods have the main role in the acquisition stage, as well as during the subsequent processing of the seismic data and, finally, the interpretation of the data which the first descriptions of the basin, both structurally and stratigraphically, is acquired (Alsadi, 2017). For all the phases mentioned above, an excellent application of seismic methods is needed, or else there can be large losses of invested money, such as in the Penobscot Field located offshore in Nova Scotia, where a 3D seismic acquisition was performed by the Nova Scotia Offshore Petroleum Board back in 1991, with an approximate area of $66 \mathrm{Km}^{2}$ $(5.5 \mathrm{Km} \times 12 \mathrm{Km})$, where subsequently a problem in the interpretation of the data was found in the travel times of the seismic waves.

This area is comprised of clastic and carbonate sequences which were formed from the Pangea rupture stage, later depositing the interest formations in this research (Wyandot and Mississauga Formation) Wyandot being a carbonate platform from the Late Cretaceous and, moreover, this formation caused the problem in

Corresponding author: Wilmer Emilio García Moreno

Wilgm93@gmail.com travel time, due to an imperceptible anomaly (around 12m) (García \& Omaña, 2019), while the Mississauga Formation is a sandstone and the target formation is in the exploratory phase, due to the possible existence of hydrocarbon in it. However, for the present investigation, this formation is the focus because of the travel time problems.

It is necessary to mention that, in its exploration phase of the Penobscot Field, two wells were drilled (Penobscot L-30 and Penobscot B-41) which had the main objective to verify the existence of hydrocarbons in two structural highs that are in contact with reverse faults, however, the obtained results were not entirely positive, because well B-41 was not a producer, although traces of oil were found in it (Crane \& Clack, 1992).

When the data was being interpreted, an advance in the travel times was found in the Mississauga Formation (approximately 15ms) in the vicinity of well B-41 which could possibly be caused by a discrepancy in the closing times in the time maps in comparison to similar ones in depth (Campbell et al., 2015). This anomaly could be produced by sudden velocity changes in shallow regions, since a hypothesis similar to this was declared in the interpretation report (Crane \& Clack, 1992) which mentions this as the main cause of the Wyandot formation. On the other hand, the advance in time could have 


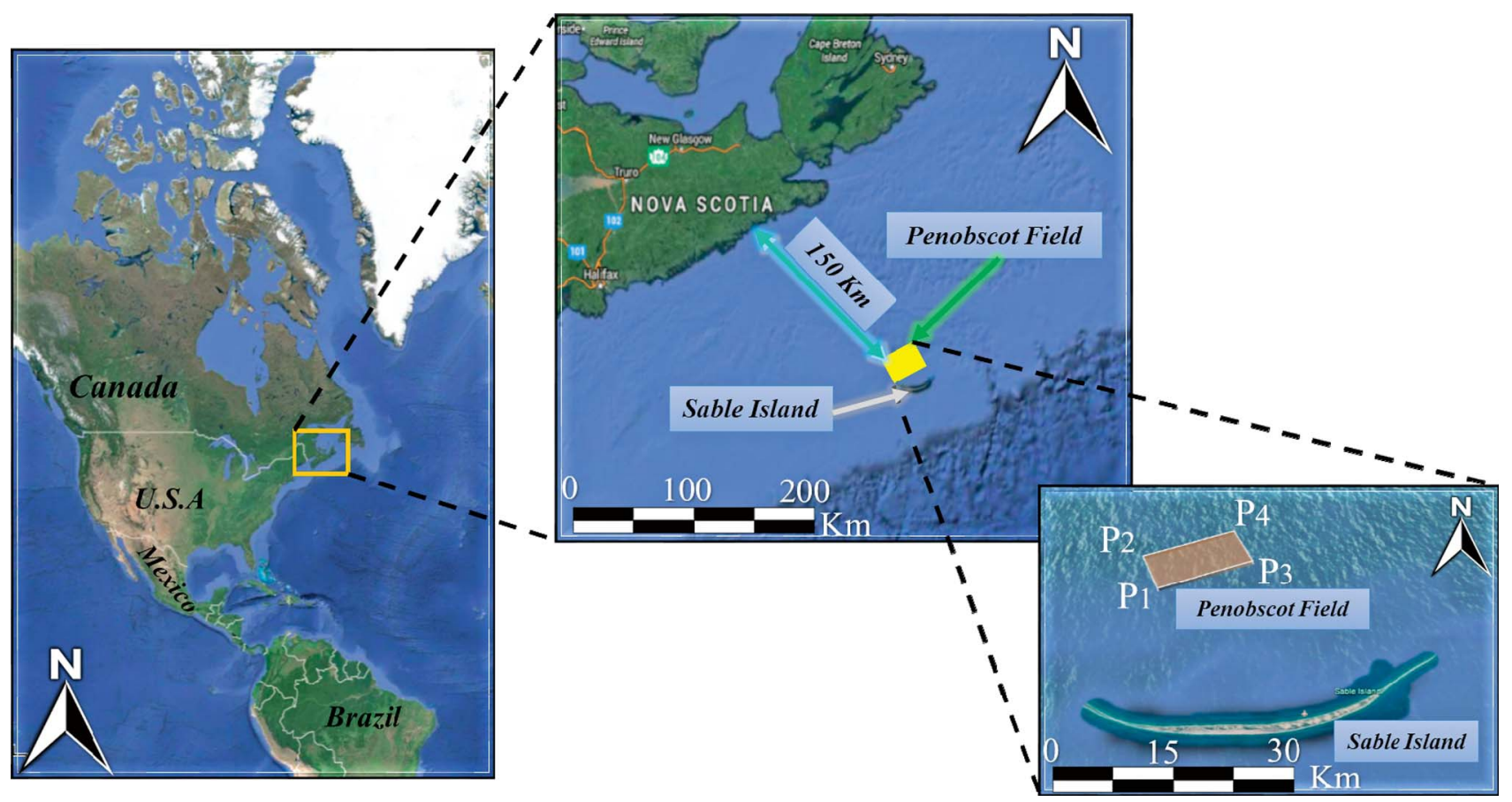

Figure 1: Location of the study area.

Table 1: Coordinates of the Seismic Cube of the Penobscot Field, based on the Spheroid with central meridian of $-63^{\circ}$ according to North American Datum NAD83

\begin{tabular}{|l|l|l|}
\hline Corners & North coordinate & East coordinate \\
\hline $\mathbf{P}_{1}$ & 4890130.78 & 731998.45 \\
\hline $\mathbf{P}_{2}$ & 4896722.05 & 728527.16 \\
\hline $\mathbf{P}_{3}$ & 4895689.47 & 742633.34 \\
\hline $\mathbf{P}_{4}$ & 4802330.74 & 739162.05 \\
\hline
\end{tabular}

happened by not taking into account the anomaly in the seismic processing stage due to the fact that it was imperceptible (García \& Omaña, 2019).

It was possible to identify such an anomaly by means of seismic and petrophysical analyses (attributes and well log analyses), delimiting it laterally and vertically, observing that it was imperceptible to seismic resolution (García \& Omaña, 2018).

Due to the previously reported literature, which also stated the importance of seismic methods, this study aimed to apply the use of synthetic models to solve problems of this type which could not only be applied to this field, but also can be applied in other regions, obtaining better seismic sections and better comprehension about anomaly behaviours.

It was decided to use a seismic subvolume where the anomaly was delimited, to interpret as many surfaces as possible, which in conjunction with petrophysical analyses (Gardner's equation) (Gardner, 1974), generates a geological model obtaining synthetic seismic gathers (via ray tracing and seismic acquisition) with the purpose of correcting the effect caused by the anomaly in the processing phase.

\section{Geographical location of the study area}

The study area is located in Canada, specifically in the Nova Scotia Basin, Sable Sub-basin, southeast of the country and northeast of Sable Island (see Figure 1), a region corresponding to a passive margin transition zone and the seismic cube coordinates are shown in Table $\mathbf{1 .}$

\section{Tectono-stratigraphic evolution of the Nova Scotia Basin}

This basin has four tectonic processes (pre-rift, synrift, early post-rift and late post-rift) which were the cause of the tectono-stratigraphic evolution, giving rise to each of the formations.

\subsection{Pre-rift}

Before the rupture phase, the Nova Scotia Basin consisted of platforms and depocenters, whose limits could be defined in some regions by oceanic fractures where their extensions reached the surface (Welsink et al., 1989). On the other hand, there was a subsidence due to thermal effects, which occurred by an increase in the depth of the basement, subsequently giving rise to the formation of the basin in the Pangea rupture (Sayers, 2013).

\subsection{Syn-rift}

The rupture of the ocean floor began in the Upper or Late Triassic, about 225 million years ago and, by that time, the basin was in a quasi-equatorial position, shar- 


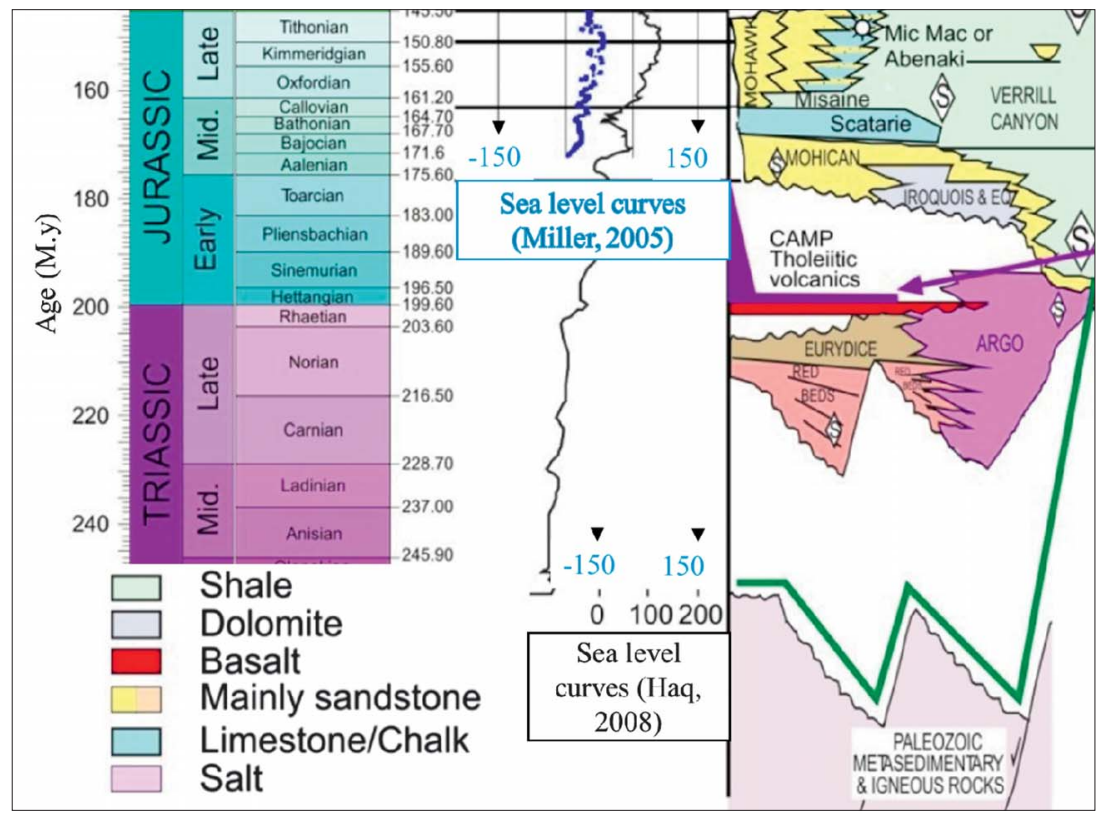

Figure 2: Lithostratigraphic column during the Triassic and Jurassic. Modified from Smith et al. (2015)

ing territory with what it is nowadays known as Morocco, and therefore, the Palaeozoic rocks of both areas have affinity, and this rupture carried on until the expansion of oceanic floor in the Early Jurassic period (Wade \& MacLean, 1990; Albertz, et. al., 2010). Due to tectonism, the Tethys Ocean started to expand, having the deposition of carbonate and clastic sediments (Iroquis and Mohican Formation; McIver, 1972), after that in the Middle Jurassic the Abenaki, Mohawk, Mic-Mac and Verrill Canyon Formations were deposited (see Figure
2), having a great deposit complexity (Weston, et al., 2012).

\subsection{Early post-rift}

By this time, the seabed was already deeper, approximately $1000 \mathrm{~m}$, in the Middle Jurassic, forming a carbonate platform (Abenaki Formation), however, in the Late Jurassic, these platforms were cut by rivers when the sea level dropped, thus forming complex deltas and transporting a significant amount of clastic sediments depos-

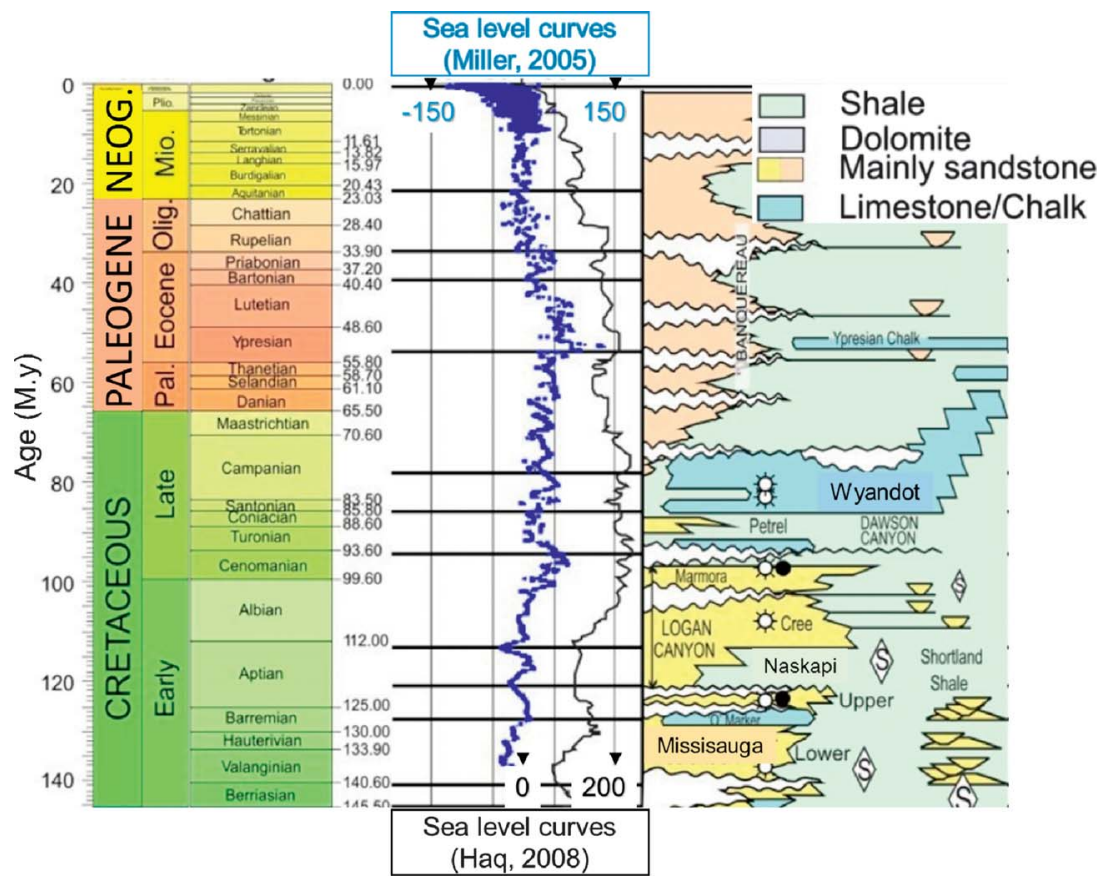

Figure 3: Lithostratigraphic column during the Cretaceous, Tertiary and Quaternary. Modified from Smith et al. (2015) 
iting into the Mic-Mac Formation (Kidston, et al., 2002; Weston et al., 2012).

\subsection{Late post-rift}

This tectonic stage was when most of the formations were deposited, beginning with the deposition of Mississauga Formation members (Middle and Lower) (Wade \& MacLean, 1990; Jansa and Noguera, 1990) separated by a diachronic, carbonated and seismic marker on the platform (O-Marker) in the early Cretaceous (PePiper \& Mckay, 2006). Due to regional transgression, the shales of the Naskapi Member were deposited, this same process was the cause of the $1200 \mathrm{~m}$ thick deposit of the Logan Canyon Formation. In the late Cretaceous, the basin had a rise in sea level, during this process the deposit of the Wyandot Formation (carbonate) occurred, however, it was observed that this formation suffered massive transport that reworked the limestone and moved it towards the basin as described by Smith et al. (2010). Finally, upon the Wyandot Formation, mudstone

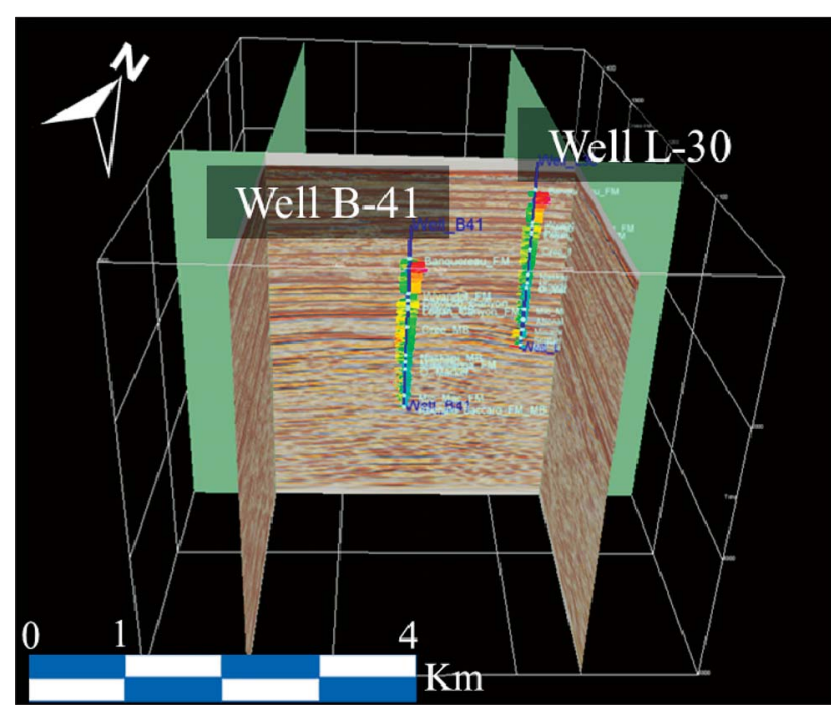

Figure 4: Seismic sub volume used and positions of the wells (seismic measurement was $6000 \mathrm{~ms}$ )

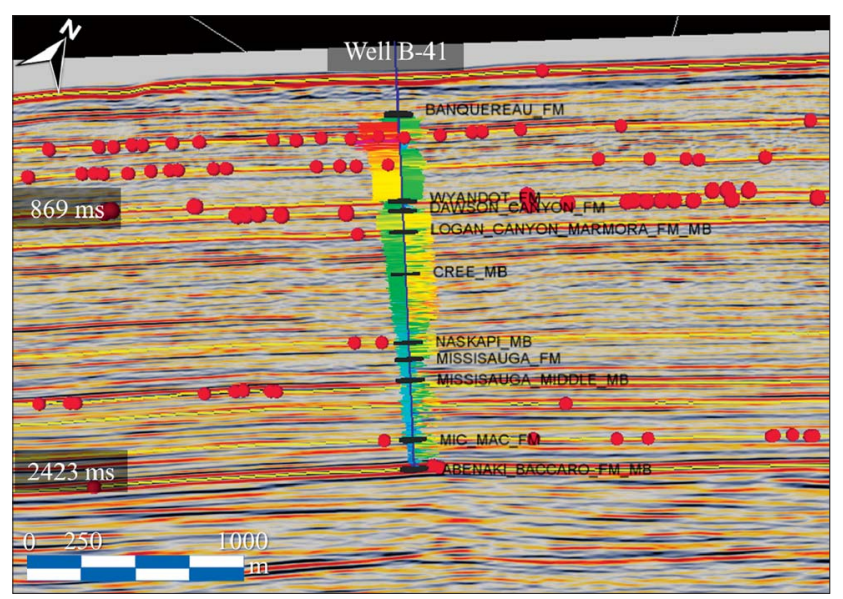

Figure 5: Well B-41 calibrated with seismics (red dotted spheres are where it was picked) and sandstone were deposited in the Cainozoic, and gave rise to the Banquereau Formation (McIver, 1972) (see Figure 3).

\section{Methodology}

All the data used in this research was derived from two wells (L-30 and B-41) and a seismic cube which was reduced because the acquisition area was larger than the problem area, which led to a seismic subvolume with an area of $16 \mathrm{~km}^{2}$ (4 km x $4 \mathrm{~km}$ ) (see Figure 4). It should be noted that these wells were already calibrated with seismics (García \& Omaña, 2018; Figure 5), therefore, we proceeded to interpret the seismic horizons of interest.

\subsection{Interpretation of seismic horizons}

In order to have a good simulation by ray tracing, a large number of surfaces should be interpreted, and for that reason, twelve seismic horizons of interest were interpreted (see Figure 6), which were:

- Eight formation tops (Banquereau, Wyandot, Dawson Canyon, Logan Canyon, Mississauga superior, Mississauga media, Mic-Mac and Abenaki).

- One member (Naskapi)

- One regional marker (O-Marker)

- Two maximum flooding surfaces (MFS) belonging to the Banquereau formation.

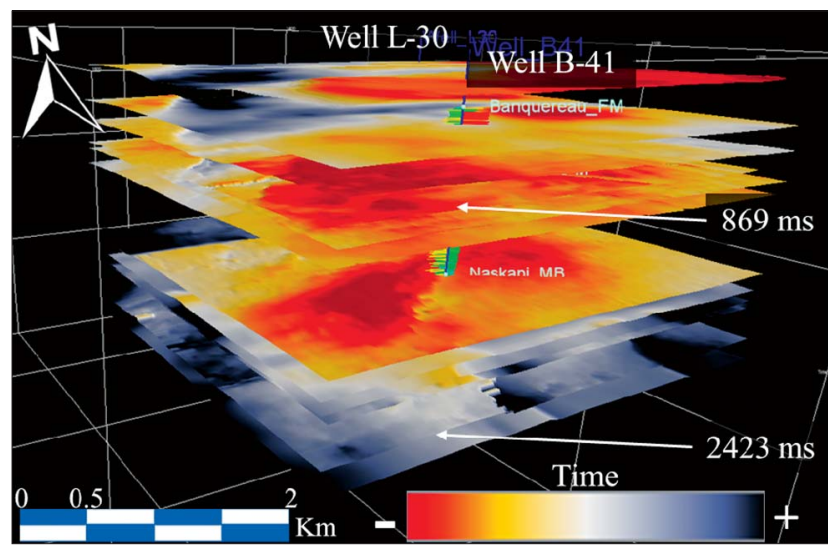

Figure 6: Interpreted seismic surface

\subsection{Geomechanical modelling}

A diversity of factors influence the coefficients of seismic reflection, such as velocity and density of rocks, which is why one can get a relationship between them and as a result, the reflection coefficients can be obtained from velocity (Gardner et al., 1974).

Due to the inside of the upper region of well logs, where there was no speed and density information and keeping in mind that there is a relationship between these properties, it was decided to model them, both in clays (Banquereau Formation) and carbonates (Wyandot Formation), thus obtaining two velocity-density and ve- 
locity-depth relationships, completing, in this way, the logs for both wells.

\subsection{Properties and synthetic geological section}

To obtain the properties of a geological model, first, all the interpreted surfaces were converted from time to depth, by means of a RMS cube (see Figure 7). Subsequently, by analysing both wells, the average velocity and density properties were obtained, as well as an ap-

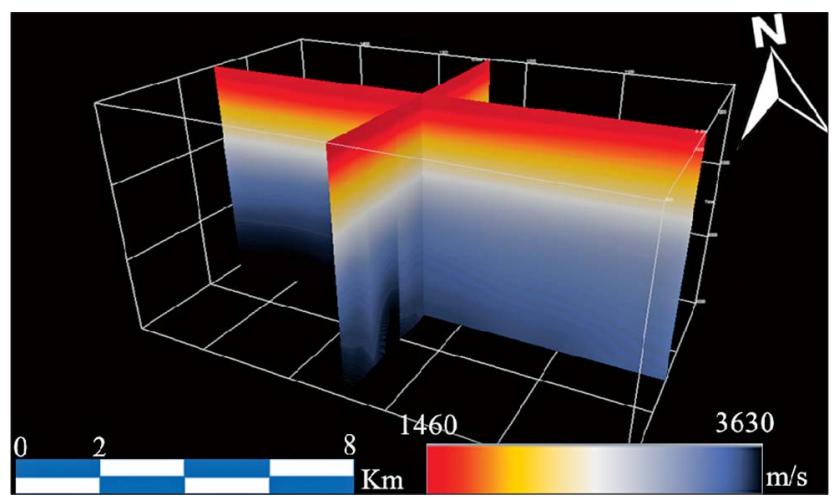

Figure 7: RMS cube

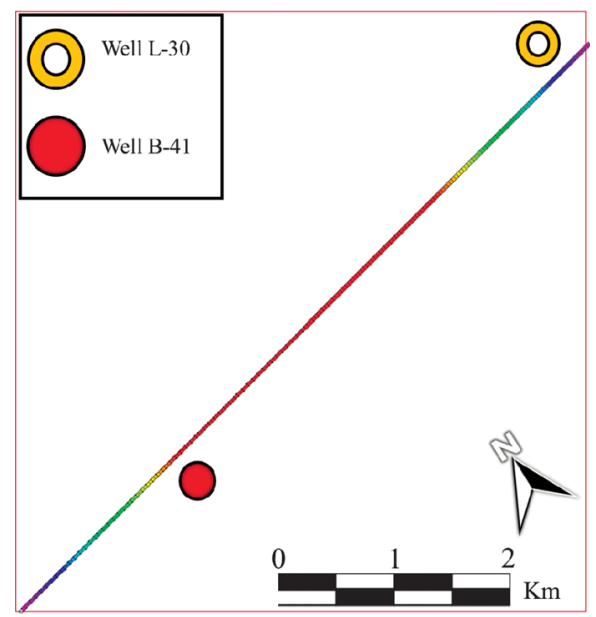

Figure 8: A 2D section and the wells' locations

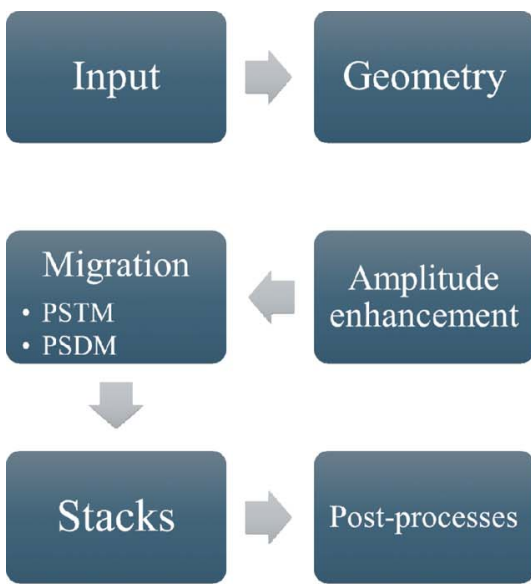

proximate thickness of each of the horizons. As the goal was to examine the effects of the anomaly in deeper lithologies (Naskapi Member and Mississauga Formation) where it was observed before, these formations were flattened to perceive if any problem could occur (false structural high after ray tracing). After these steps, a 2D-section was taken between both wells, in which all acquisition aspects were simulated (see Figure 8).

\subsection{Seismic processing}

Having the synthetic shot gathers by means of ray tracing, the subsequent step was to perform them by seismic processing to initially observe the effect of the anomaly and, later, to be able to solve it by making use of the processing sequence established next in Figure 9.

\section{Results}

\subsection{Interpretation of seismic horizons}

Interpretations of twelve relevant seismic surfaces were performed (see Figure 10), in order to do a good ray tracing, simulating as many surfaces as possible. The surfaces presented in Figure $\mathbf{1 0}$ are ordered according to their depth with the Banquereau Formation being the shallowest and Abenaki the deepest. Also, it can be seen that in the vicinity of Well B-41 from the Mississauga Formation, an interpreted structural high exists.

\subsection{Completing the logs by geo-mechanical modelling}

During the geo-mechanical modelling, the functions observed in Table 2 were obtained by means of the different graphs shown in Figure 11, Figure 12 and Figure 13, for clays and carbonates in both wells. In Figure 11, it can be seen that while the velocity is growing, the density is higher too, since carbonates have faster lithology. Another remarkable thing is that in Well B-41, the minimum density is higher than in Well L-30. On the other hand, the logs could be completed in velocity and den-

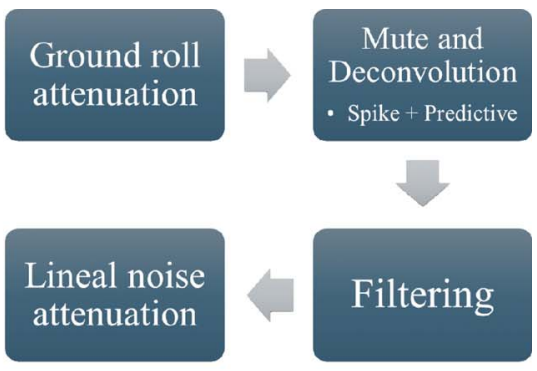

Figure 9: Seismic processing workflow 

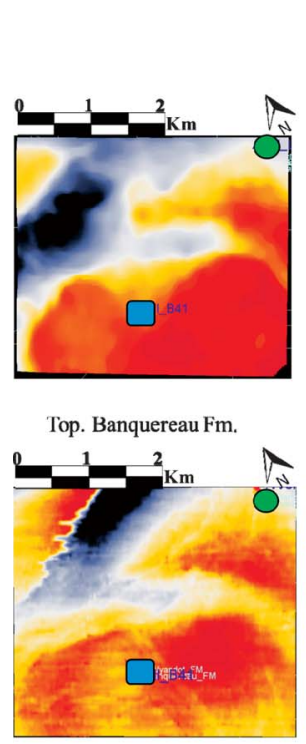

Dawson Canyon Fm.

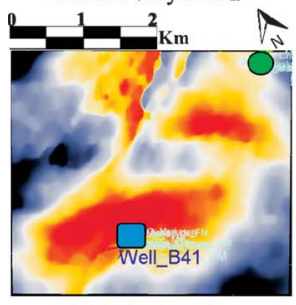

O-Marker Member

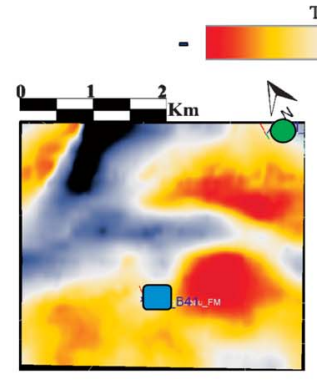

MFS 1 in Banquereau Fm.

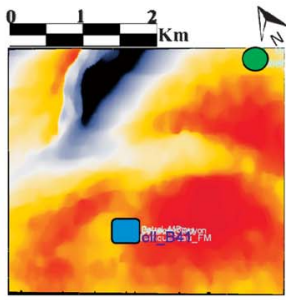

Logan Canyon Fm.

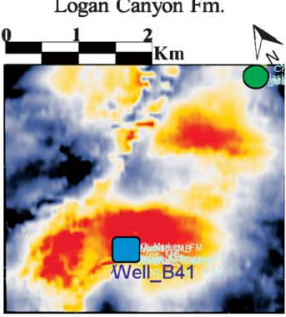

Missisauga Fm. (middle)

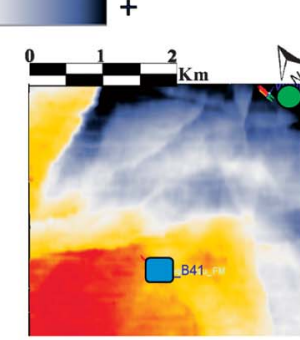

MFS 2 in Banquereau Fm.

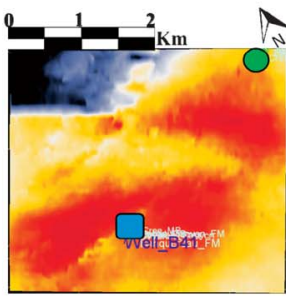

Naskapi Member

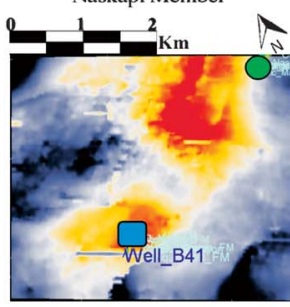

Mic-Mac Fm.

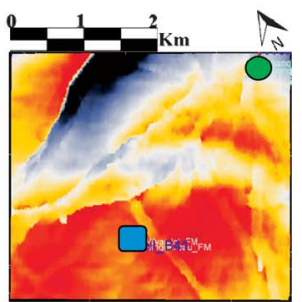

Wyandot Fm.

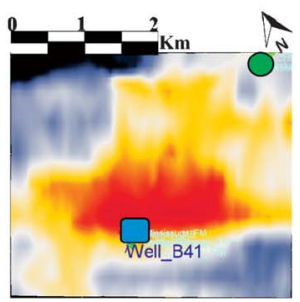

Missisauga Fm. (top)

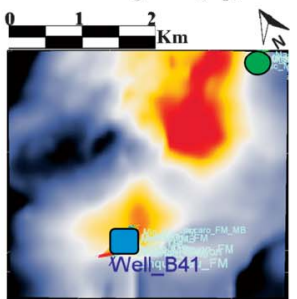

Abenaki Fm.

Figure 10: Seismic surface interpreted corresponding to some formations, members and MFS as listed in the figure (Blue square: Well B-41; Green circle: Well L-30)
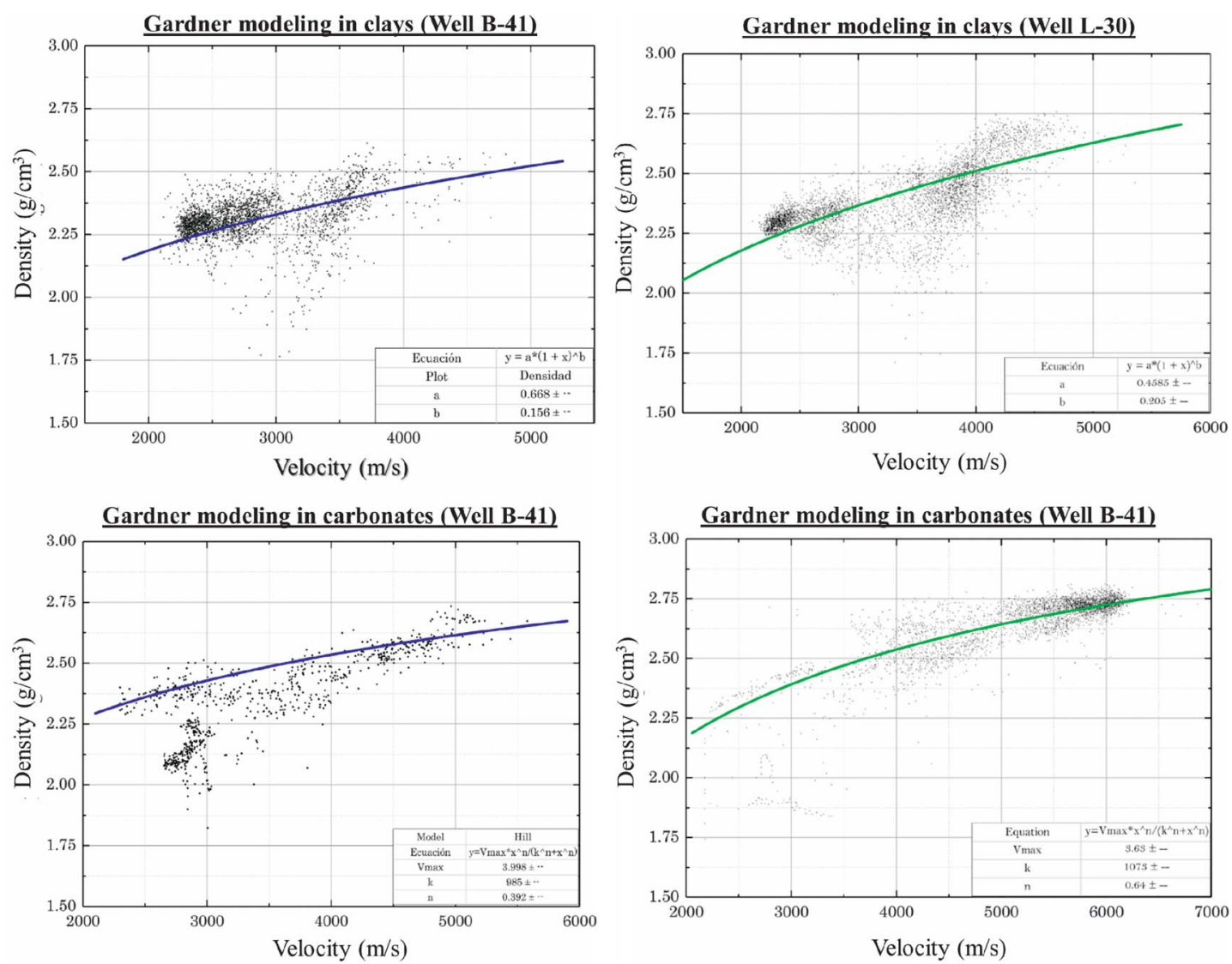

Figure 11: Gardner modelling in both wells 

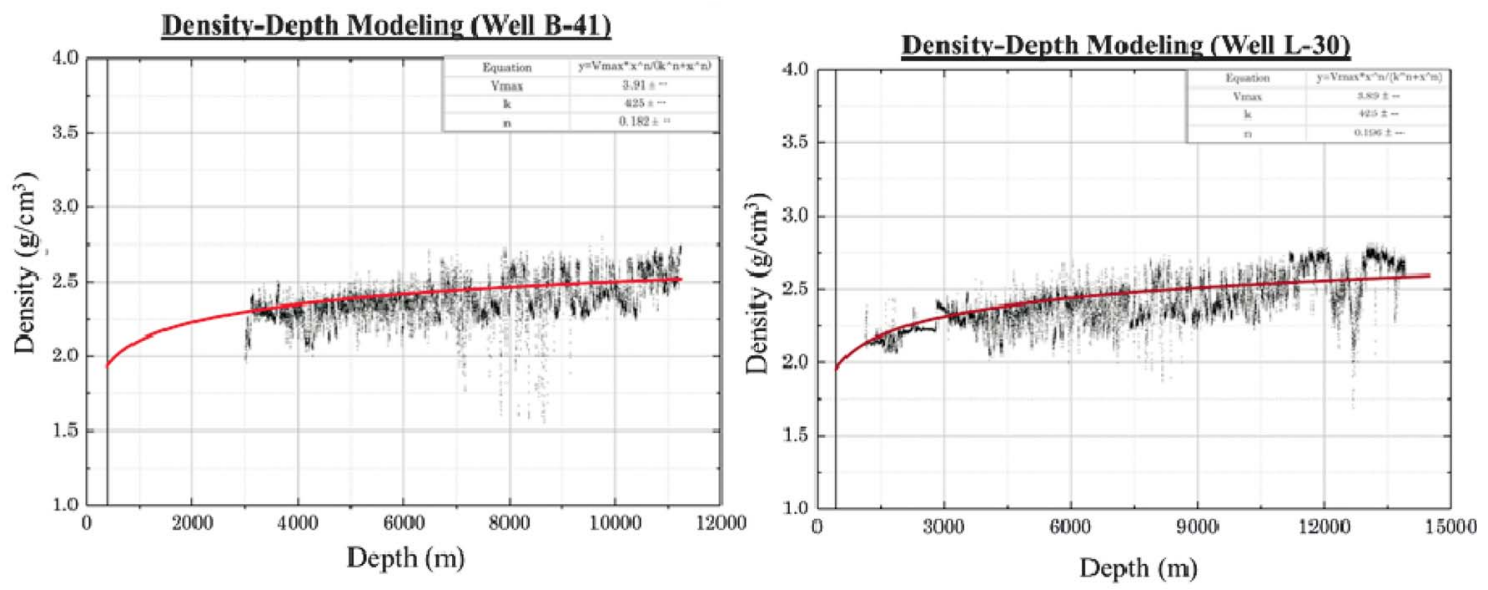

Figure 12: Density vs depth in both wells

Density log in depth completed by Gardner (Well B-41)

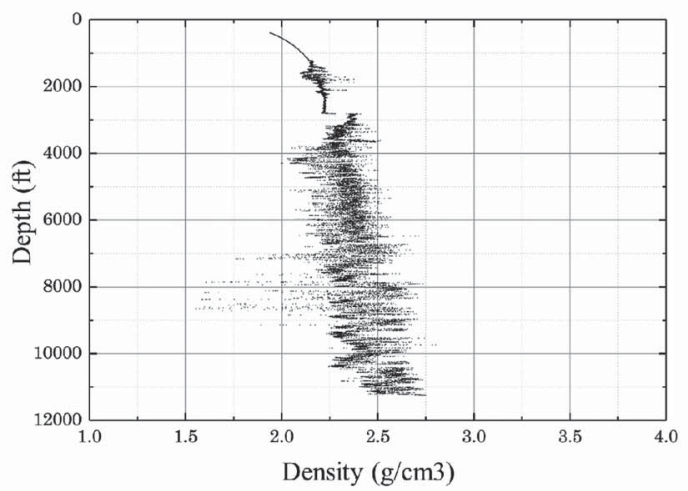

Velocity log in depth completed by Gardner (Well B-41)

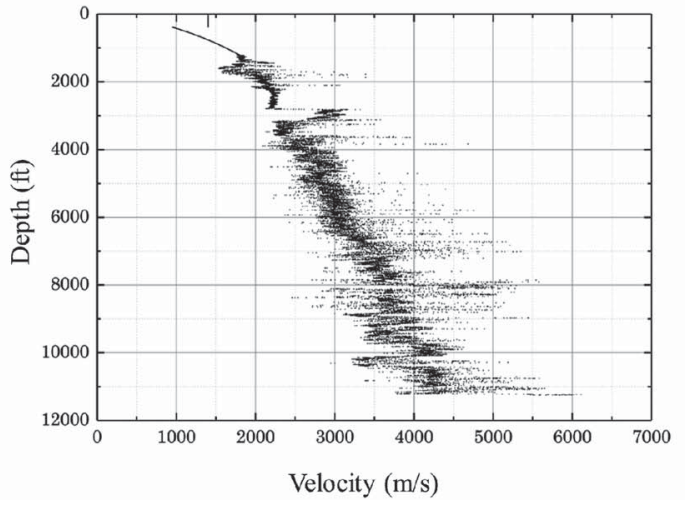

Density log in depth completed by Gardner (Well L-30)

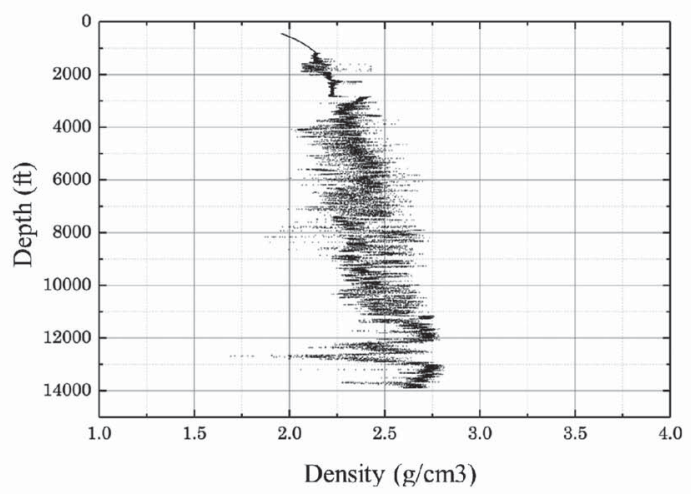

Velocity log in depth completed by Gardner (Well L-30)

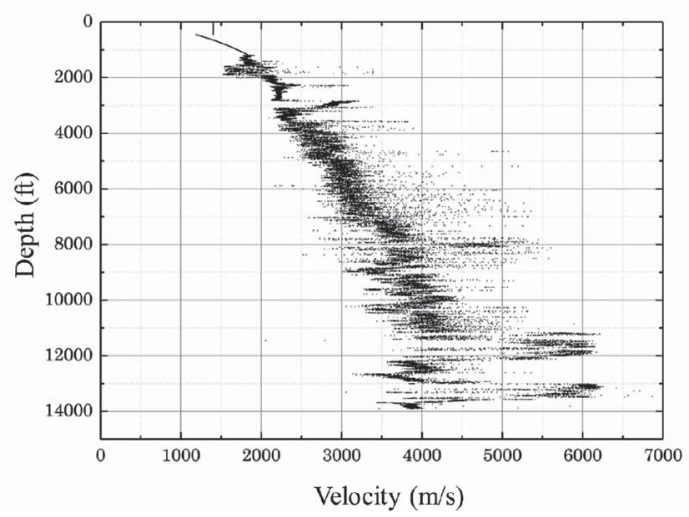

Figure 13: Density and velocity logs completed in both wells $(\mathrm{Ift}=0.3048 \mathrm{~m})$

Table 2: Functions attained by Gardner's equations

\begin{tabular}{|c|c|c|}
\hline & Well B-41 & Well L-30 \\
\hline Gardner (Clay) & $\rho=0.668(1+V e l)^{0.156}$ & $\rho=0.4585(1+V e l)^{0.205}$ \\
\hline Gardner (Carbonates) & $\rho=3.998(\mathrm{Vel}) \frac{0.392}{)^{985^{0.392}+\mathrm{Vel}^{0.392}}}$ & $\rho=3.63(\mathrm{Vel}) \frac{0.64}{1073^{0.64}+\mathrm{Vel}^{0.64}}$ \\
\hline Density vs Depth & $\rho=3.91(\mathrm{Vel}) \frac{0.182}{425^{0.182}+\mathrm{Vel}^{0.182}}$ & $\rho=3.89(\mathrm{Vel}) \frac{0.196}{425^{0.196}+\mathrm{Vel}^{0.196}}$ \\
\hline
\end{tabular}


Table 3: Properties for every layer in the geological model

\begin{tabular}{|c|c|c|c|c|}
\hline Surface & Velocity $(\mathrm{m} / \mathrm{s})$ & Density (g/cc) & Formation & Thickness (m) \\
\hline Water column & 1400 & 1 & - & 127 \\
\hline Banquereau & 1350 & 2.05 & \multirow{3}{*}{ Banquereau } & 305 \\
\hline MFS1 & 1800 & 2.13 & & 175 \\
\hline MFS2 & 2100 & 2.19 & & 255 \\
\hline Wyandot & 2866 & 2.36 & \multirow{2}{*}{ Wyandot } & 97 \\
\hline Anomaly & 3574 & 2.44 & & 12 \\
\hline Dawson Canyon & 2503 & 2.30 & Dawson Canyon & 233 \\
\hline Logan Canyon & 3047 & 2.33 & \multirow{2}{*}{ Logan Canyon } & 947 \\
\hline Naskapi & 3485 & 2.36 & & 103 \\
\hline Mississauga Superior & 3651 & 2.32 & \multirow{3}{*}{ Mississauga } & 158 \\
\hline O Marker & 4323 & 2.50 & & 49 \\
\hline Mississauga M-L & 3841 & 2.42 & & 725 \\
\hline Mic-Mac & 4282 & 2.54 & Mic-Mac & 286 \\
\hline Abenaki & 5307 & 2.66 & Abenaki & 450 \\
\hline
\end{tabular}

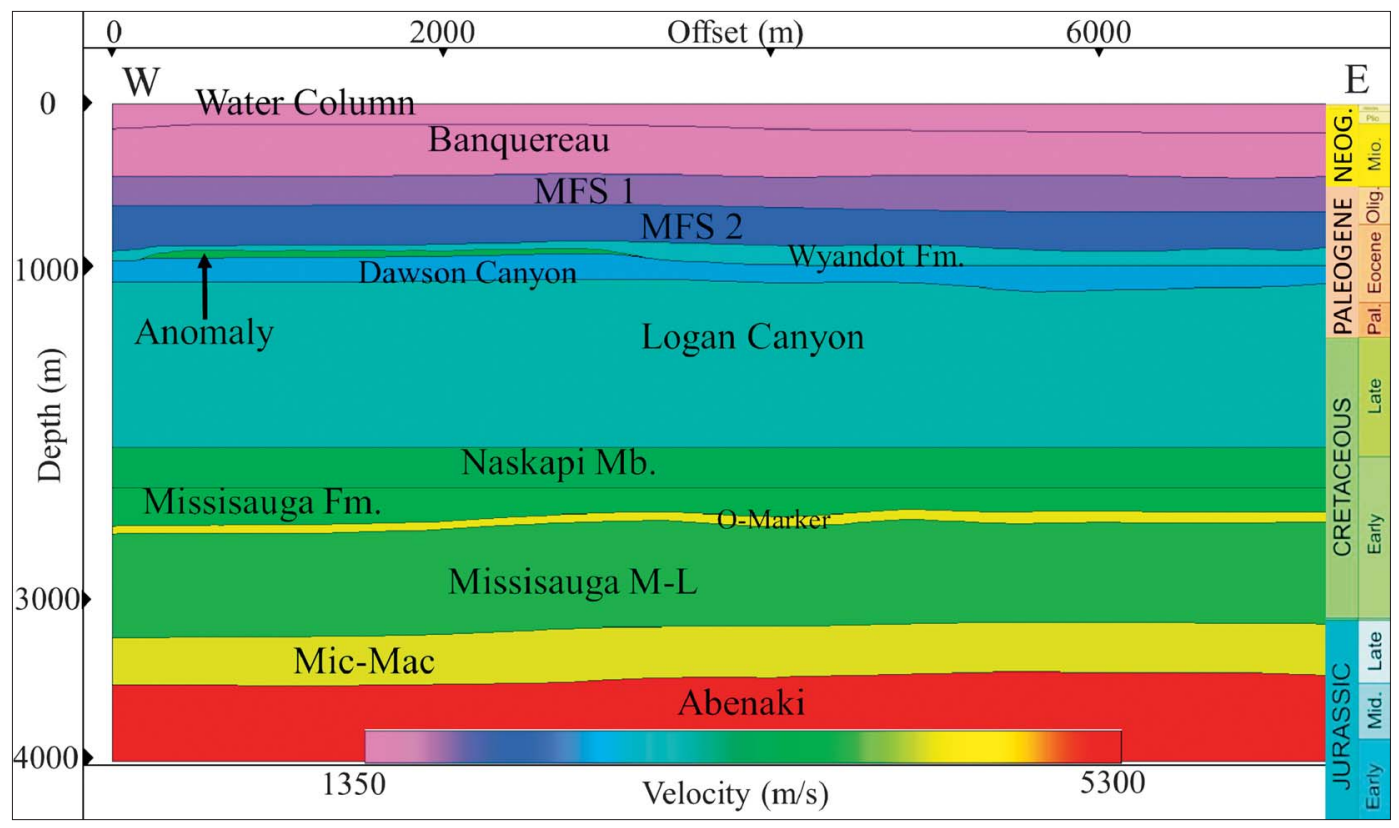

Figure 14: Synthetic geological model

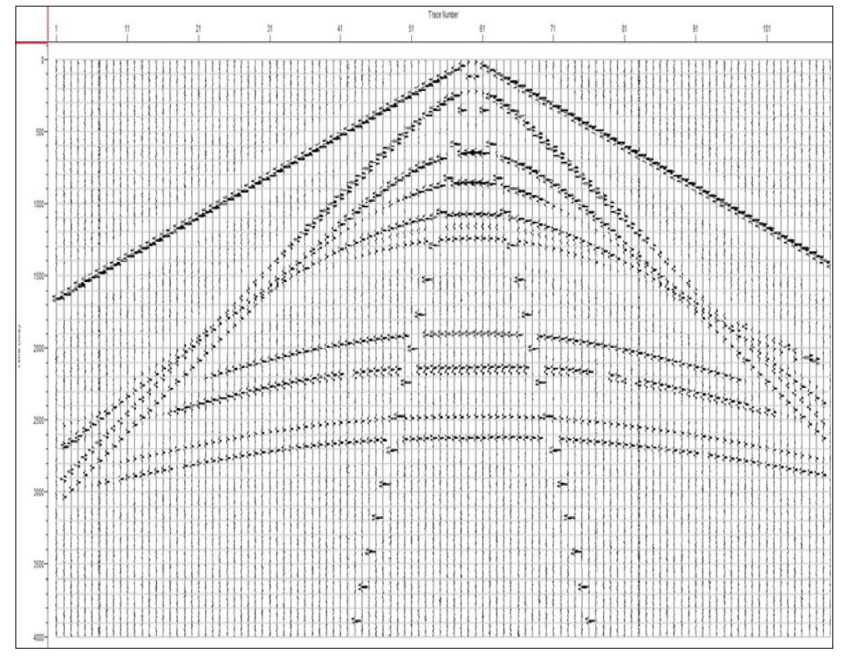

Figure 15: Synthetic shot gather \#59
Table 4: Properties of synthetic gathers

\begin{tabular}{|l|c|}
\hline Property & Value \\
\hline Wavelet & Ricker \\
\hline Refraction velocity $(\mathrm{m} / \mathrm{s})$ & 2500 \\
\hline Refraction frequency $(\mathrm{Hz})$ & 30 \\
\hline Refraction amplitude & 2 \\
\hline Ground roll velocity $(\mathrm{m} / \mathrm{s})$ & 300 \\
\hline Ground roll frequency $(\mathrm{Hz})$ & 10 \\
\hline Ground roll amplitude & 4 \\
\hline Reflection frequency $(\mathrm{Hz})$ & 25 \\
\hline Reflection amplitude & 1 \\
\hline Traces length (ms) & 4000 \\
\hline Sampling interval $(\mathrm{ms})$ & 2 \\
\hline
\end{tabular}


sity having the same tendency as was graphed in Figure 12, getting finally Figure 13.

\subsection{Properties and synthetic geological section}

After having the information of density and velocity in each well, we proceeded to delimit each surface in depth and, thus, obtaining the properties mentioned in each interval, (the average values are summarized in Table 3)

Subsequently, by converting the surfaces from time to depth, a 2D geological model was obtained (see Figure 14) and the anomaly was observed, as well as two com-
Raw Data

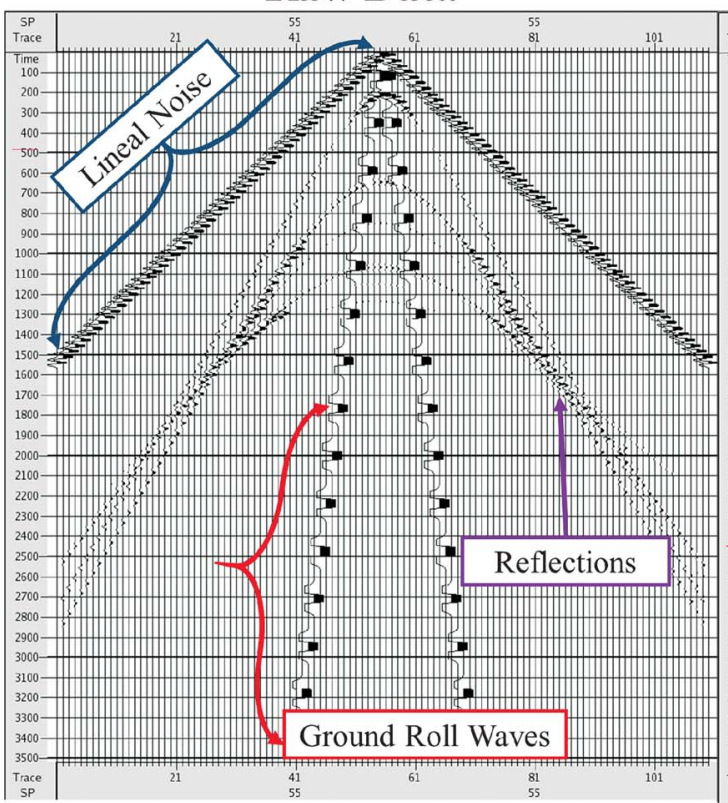

Amplitude Enhancement

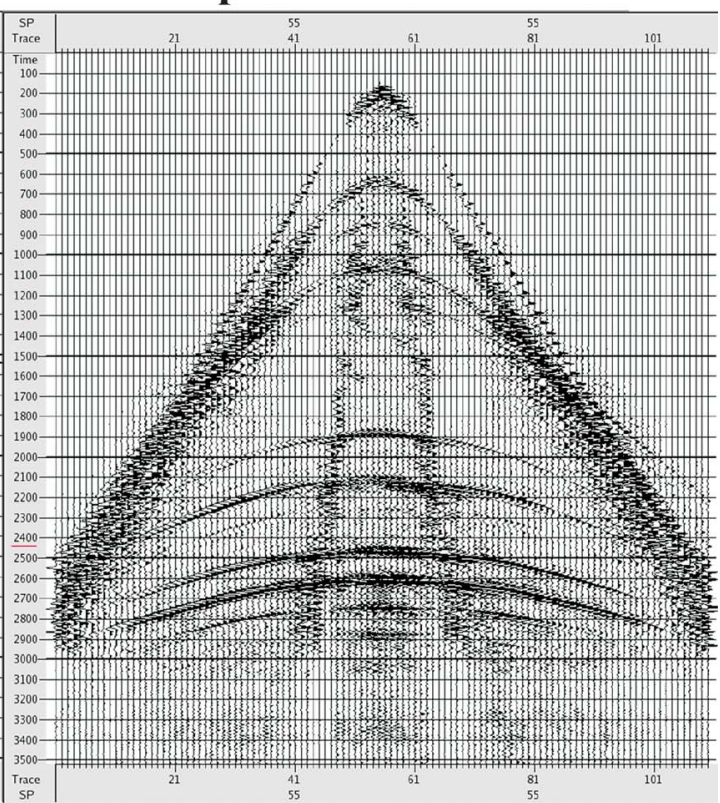

Figure 16: Raw data and gather after applying the step named "Amplitude enhancement"

PSTM

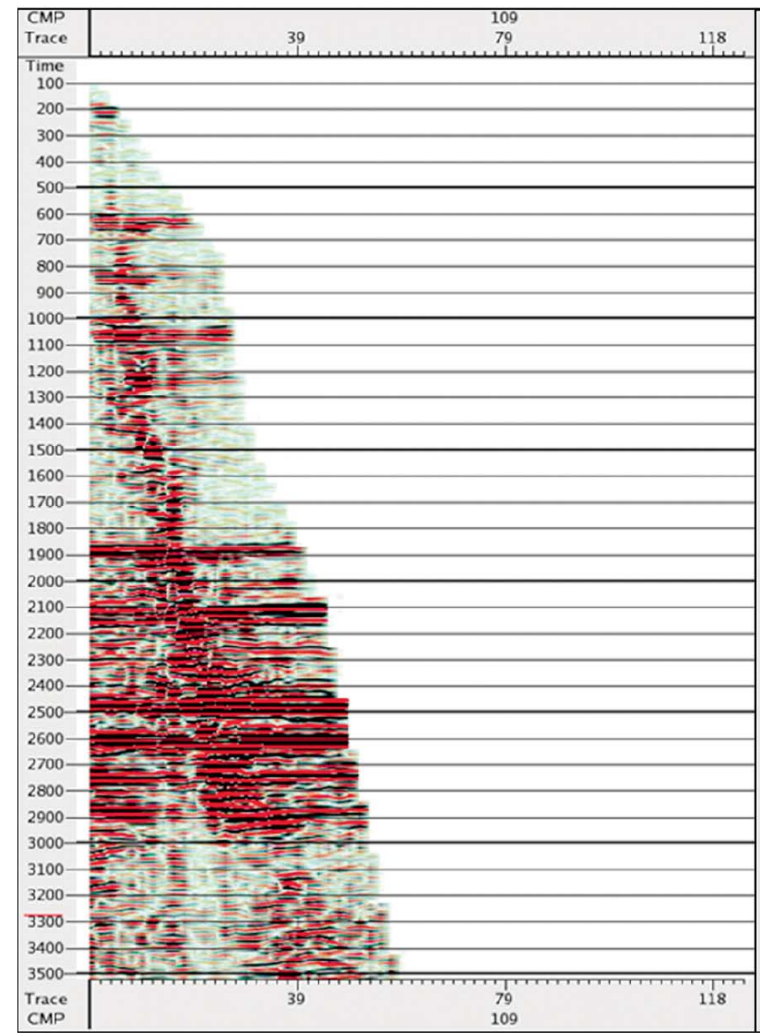

PSDM

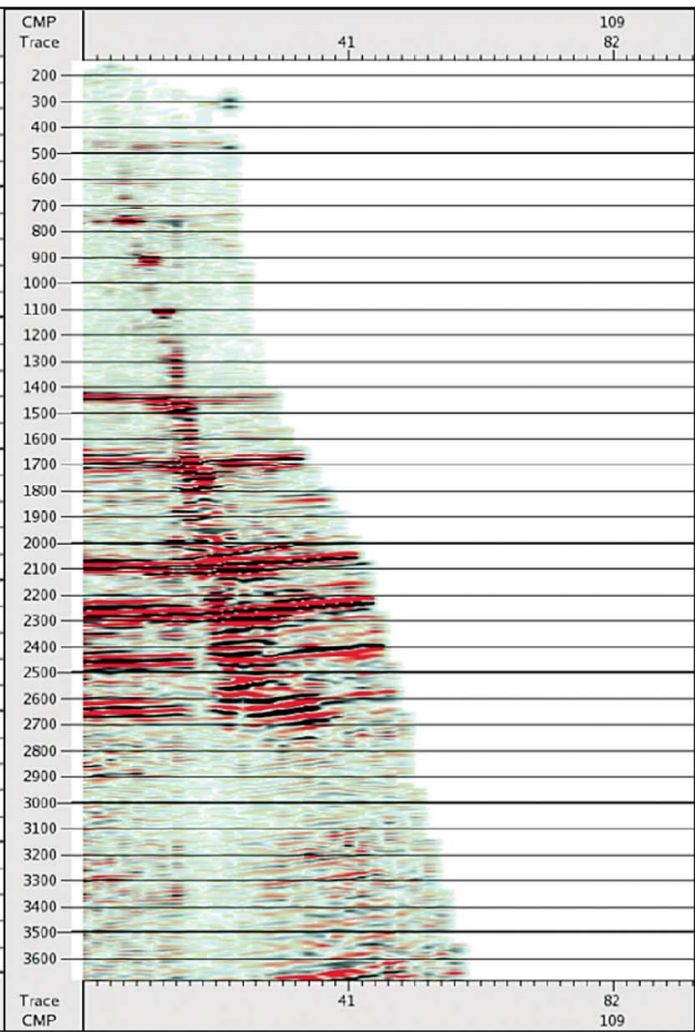

Figure 17: Gather after applying Kirchhoff pre-stack migration in time (PSTM) and depth (PSDM) 


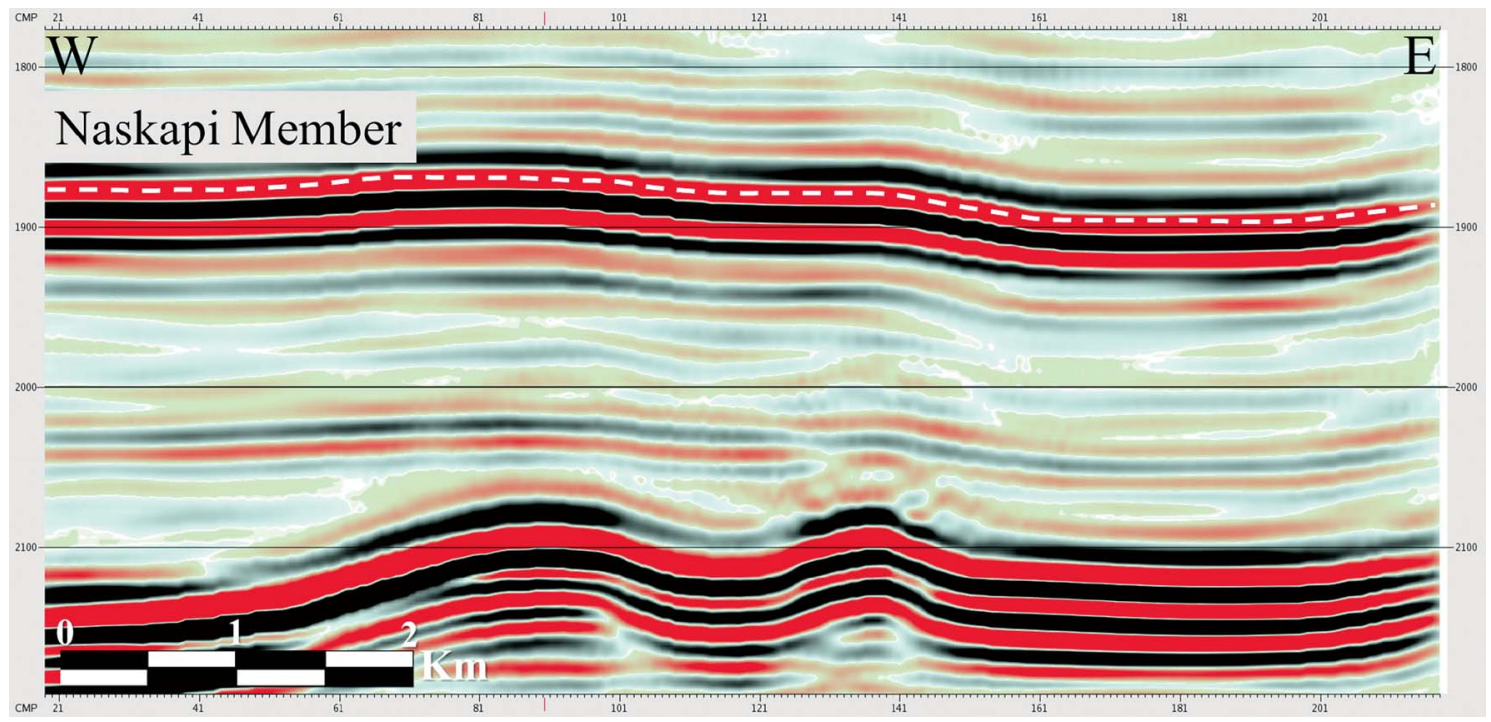

Figure 18: Stack of PSTM zoomed on the problem area

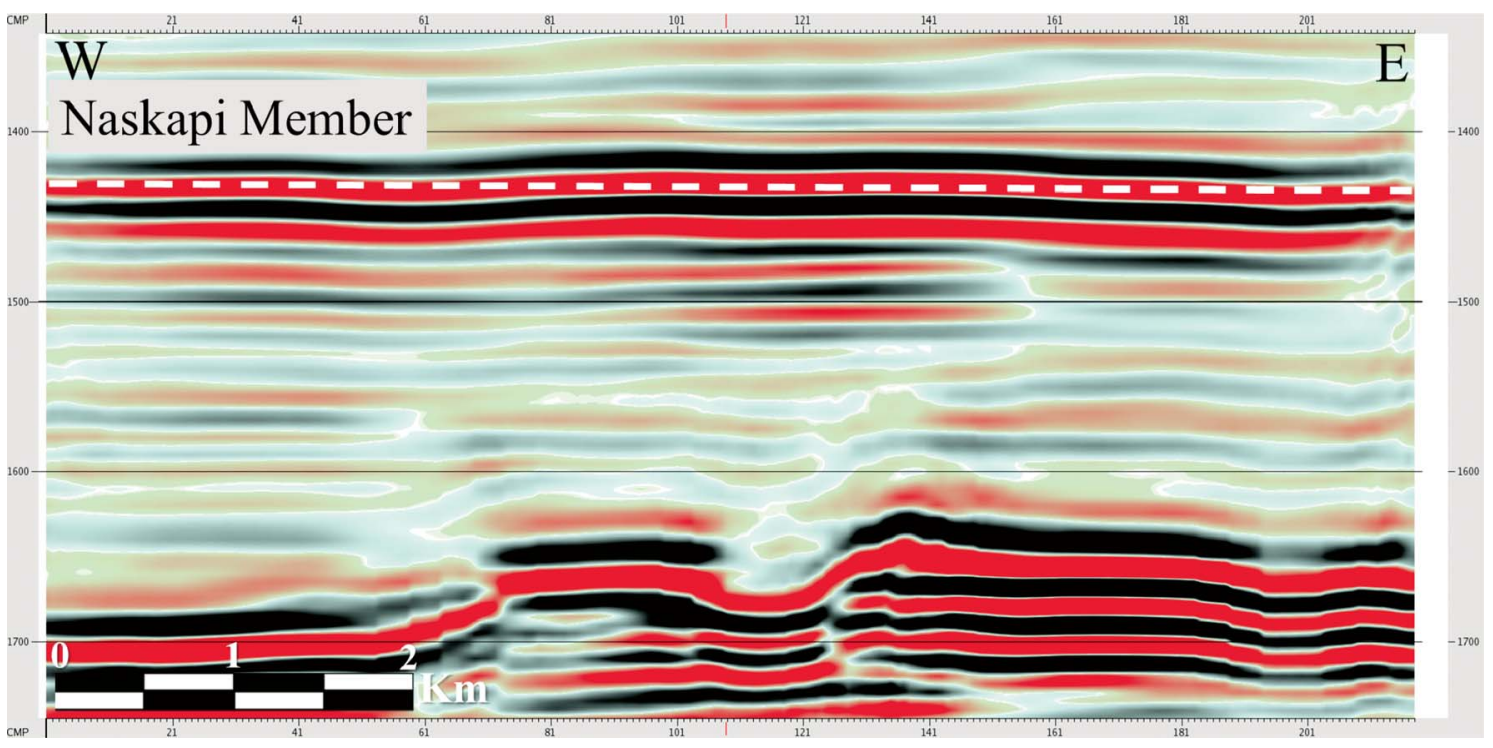

Figure 19: Stack of PSDM zoomed on the problem area

pletely flat seismic horizons that represent the Naskapi Member and the Mississauga Formation.

\subsection{Ray Tracing}

An acquisition survey was designed for the geological section shown in Figure 14, which was simulated by ray tracing, obtaining a set of 110 shot gathers, like the one shown in Figure 15, obtaining the properties shown in Table 3.

\subsection{Seismic processing}

The first thing to do was to load the raw data (see Figure 16) to apply the seismic processing sequence (see Figure 9) to attenuate the existing noise and obtain a greater amplitude of the reflections and achieve the solution to the problem caused by the anomaly. For that reason, in the raw data where the reflection had low amplitude, seismic processing flow was applied, thus improving the amplitude. Also, it was possible to remove the existing noise and perceive the deepest reflections without any problems.

On the other hand, after having the gathers with a good reflection amplitude, the two algorithms of Kirchhoff pre- stack migration (see Figure 17) were applied in time (PSTM) as it was applied in the original data processed by CNSOPB and in depth (PSDM) because it was thought that it could eliminate any anomalous effect. In this way, the PSTM and PSDM were stacked to notice the effects caused by the anomaly in the Wyandot Formation and after that, the post-processes were applied (see Figure 18 and Figure 19)

After stacking, the PSTM gathers an uplift in the Naskapi member that is still noticeable (see Figure 18), 
even when this horizon in the geological model was flattened, however, when stacking in depth migrated gathers, it shows how the horizon (Naskapi Member) applying PSDM is flatter than the PSTM, getting a correction of the effect of the high-velocity anomaly caused inside the Wyandot Formation.

\section{Conclusions}

A pre-stack depth migration algorithm could provide the best possible response for complex structures, but in this study, it was seen that this is also true for subtle changes in velocity of a formation that can cause large differences (anomalies). Having, thus, a more real seismic section, which will subsequently reduce those effects.

In this way, a possible solution to the problem was found, firstly it was needed to identify the problem area to know how to act, which in this case, synthetic modelling was used. By means of synthetic modelling and ray tracing, it was noticeable how an imperceptible stratum with high velocity could affect the final seismic section. Even when this investigation was carried out taking into account a high velocity anomaly, this could be applied for an inverse case (low velocity anomaly) because it could be observed in the seismic section in an event deeper than it really is.

Also, with this research, it was possible to make a comparison between PSTM and PSDM noticing that PSDM gives a better (and more realistic) seismic section, however, to achieve this, a good seismic processing workflow is needed. On the other hand, synthetic modelling is a good way to obtain solutions for velocity problems in other fields too.

\section{Acknowledgement}

BGP International of Venezuela because it was the company which gave the opportunity to process the data there, using their software GeoEast 2.6.

\section{References}

Albertz, M., Beaumont, C., Shimeld, J., Ings, S., and Gradmann, S. (2010): An investigation of salt tectonic structural styles in the Scotian Basin, offshore Atlantic Canada: 2. Comparison of observations with geometrically complex numerical models. Tectonics (29). 3-7 p. DOI: 10.1029/2009TC002540.

Alsadi, H. N. (2017): Seismic Hydrocarbon Exploration - 2D and 3D Techniques (Vol. 1). Springer International Publishing. 3-4 p. DOI: 10.1007/978-3-319-40436-3.

Campbell, T., Richards, F., Silva, R., Wach, G., and Eliuk, L. (2015): Interpretation of the Penobscot 3D seismic volume using constrained sparse spike inversion, Sable sub-Basin, offshore Nova Scotia. Marine and Petroleum Geology, 68(Part A), 73-93 p.
Crane, P; Clack, P. (1992): Final report on the 3-D seismic survey on Penobscot E.L. 2353 offshore Nova Scotia. Nova Scotia: CNSOPB. 11-15 p.

García, W., Omaña, I. (2019): Identification of high velocity anomalies, imperceptible to seismic resolution, by integration of seismic attributes, in the Penobscot Field, Canada. Rudarsko-geološko-naftni zbornik (The Mining-GeologyPetroleum Engineering Bulletin) - accepted for publication in no. 44-.

Gardner, G., Gardner, L., \& Gregory, A. (1974): Formation velocity and density - The diagnostic basics for stratigraphic traps. Geophysics, 39, 770-780.

Haq, B., Schutter, S. (2008): Chronology of Paleozoic SeaLevel Changes. Science (New York, N.Y.) (Vol. 332). 6468 p. DOI: $10.1126 /$ science. 1161648

Jansa, Lubomir F., Noguera Urrea, V.H. (1990): Geology and diagenetic history of overpressured sandstone reservoirs, Venture Gas Field, Offshore Nova Scotia, Canada. Aapg Bulletin - Bulletin 74(10). 1640-1658 p.

Kidston, A., Brown, D., Altheim, B., and Smith, B. (2002): Hydrocarbon potential of the deep-water Scotian Slope. Nova Scotia: Canada-Nova Scotia Offshore Petroleum Board. Geosciences Department. 5-6 p.

McIver, N. (1972): Mesozoic and Cenozoic stratigraphy of the Nova Scotia Shelf. Canadian Journal of Earth Sciences (9) 54-70 p. https://doi.org/10.1139/e72-005.

Miller, Kenneth G., Kominz, Michelle A., Browning, James V., Wright, James D., Mountain, Gregory S., Katz, Miriam E., Sugarman, Peter J., Cramer, Benjamin S., ChristieBlick, Nicholas and Pekar, Stephen F. (2005): The Phanerozoic Record of Global Sea-Level Change. American Association for the Advancement of Science. 1293-1298 p. DOI: $10.1126 /$ science. 1116412

Pe-Piper, G., Mackay, M. (2006): Provenance of Lower Cretaceous sandstones onshore and offshore Nova Scotia from electron microscope geochronology and chemical variation of detrital monazite. Bull. Can. Pet. Geol. 54. 366-379 p. DOI: $10.2113 /$ gscpgbull.54.4.366.

Sayer, Jordan (2013): Enhancement of the geological features of The Scotian Basin by the application of spectral inversion, offshore Nova Scotia. University of Houston. Houston, Texas, United States of America. 1-25 p. URL: http:// hdl.handle.net/10657/458

Smith, B., Deptuck, M., \& Kendell, K. (2012): Upper Cretaceous Mass Transport Systems Above the Wyandot Formation Chalk, Offshore Nova Scotia. In: Mosher D.C. et al. (eds) Submarine Mass Movements and Their Consequences. Advances in Natural and Technological Hazards Research, vol 28. Springer, Dordrecht. 619-630 p. DOI: https://doi.org/10.1007/978-90-481-3071-9_50

Smith, B., Makrides, C., and Kendell, K. (2015): Call for Bids NS15-1 - Exploration history, geologic setting, and exploration potential: Eastern Region Geoscience Open File Report 2015-002MF. Canada - Nova Scotia Offshore Petroleum Board. 32p.

Wade, J., and MacLean, B. (1990): The geology of the southeastern margin of Canada, Chapter 5, Part 2: Aspects of the geology of the Scotian Basin from recent seismic and well data. DOI: https://doi.org/10.1130/DNAG-GNA-I1.167 
Welsink, H., Dwyer, J., and Knight, R. (1989): Tectono-stratigraphy of the passive margin of Nova Scotia. AAPG Memoir, 46. Chapter 14. 215-231 p.

Weston, J.F., MacRae, R.A., Ascoli, P., Cooper, M.K.E., Fensome, R.A., Shaw, D. and Williams, G.L. (2012): A revised biostratigraphic and well-log sequence-stratigraphic framework for the Scotian Margin, offshore eastern Canada12. Canadian Journal of Earth Sciences. 49. 1417-1462 p. DOI: https://doi.org/10.1139/e2012-070

\section{SAŽETAK}

\section{Rješavanje neuobičajeno velikih brzina seizmički nerazlučivih anomalija uporabom sintetičkih modela, polje Penobscot, Kanada}

Polje Penobscot nalazi se u subbazenu Sable u Novoj Škotskoj, Kanada. Tamo je 1991. načinjeno 3D seizmičko snimanje te su izbušene dvije naftne bušotine (L-3o i B-41). U interpretiranim seizmičkim podatcima uočeno je odstupanje u očekivanim seizmičkim brzinama u okolici bušotine B-41. Tako je ocrtano lažno strukturno uzdignuće unutar člana Naskapi (formacija Missisauge) i dublje (anomalija od 10 do $15 \mathrm{~ms}$ ili približno $25 \mathrm{~m}$ ). Odlučeno je taj problem riješiti uporabom sintetičkih modela. Prvo su određeni volumeni seizmičke kocke, zatim površine za analizu te su uporabom bušotinskih podataka izračunane prosječne brzine i gustoća za svaki interpretirani sloj. Nakon toga je načinjen $2 \mathrm{D}$ seizmički model, koji je obuhvatio obje bušotine, praćenje sintetskih oblika, te Kirchhoffovu preseizmičku i postseizmičku dubinsku migraciju.

\section{Ključne riječi:}

visoka brzina anomalija, formacija Missisauge, Nova Škotska, Kanada, donji i gornji kredni, Ray-Tracing, Kirchhoff PSTM i PSDM

\section{Authors contributions}

García M. Wilmer E. (Geophysical Engineer) led this research doing all the tests shown above and he wrote this paper. Omaña G. Iván D. (MSc. Earth Sciences) initialized the idea of this research, proportioning help to García, reading and making corrections in this paper before submitting. 